\title{
Incidence, risk factors and etiological agents in surgical site infections in a developing country
}

\author{
E Alp ${ }^{*}$, F Elmali, S Ersoy, C Kucuk, B Tucer, M Doganay \\ From International Conference on Prevention \& Infection Control (ICPIC 2011) \\ Geneva, Switzerland. 29 June - 2 July 2011
}

\section{Introduction / objectives}

There is limited data about the epidemiology of SSIs in developing countries.To investigate incidence rates of SSIs, risk factors, etiological agents and antimicrobial resistance rates of pathogens in a developing country.

\section{Methods}

Prospective surveillance of SSIs was performed during May 2005 and April 2009 in neurosurgery (NS) and general surgery (GS) unit. All patients who had gallbladder (CHOL), colon (COLO), gastric (GAST), small bowel (SB) and bile duct, liver or pancreatic surgery (BILI) in GS and craniotomy (CRAN), ventricular shunt (VSHN) and spinal fusion (FUSN) surgery in NS were included.

\section{Results}

SSI was determined in 415 (10.8\%) patients in GS and 146 (4\%) of patients in NS.SSI rates were $4 \%, 16.8 \%, 6 \%, 16.4 \%$ and $14 \%$ in CHOL,COLO,GAST,SB and BILI, respectively in GS.In NS, SSI rates were $4 \%, 4.8 \%$ and $4.5 \%$ in CRAN, VSHN and FUSN.Cefazolin was used in 780 (49\%) operations in GS, 1266 (95\%) of operations in NS for antimicrobial prophylaxis.Broad spectrum antibiotics were administered in the rest of the patients.Antimicrobial prophylaxis (AMP) were administered for $>24 \mathrm{~h}$ in $69 \%$ and $64 \%$ of patients in GS and NS, respectively.The most significant risk factors for SSIs were total parenteral nutrition, transfusion and presence of drain in GS, and total parenteral nutrition, transfusion, stress ulcer prophylaxis, presence of drain and foreign material in NS.The most common pathogen was Escherichia coli in GS and Acinetobacter baumannii in NS.Isolated pathogens were multiresistant, with $58 \%$ quinolone resistance in E.coli and $67 \%$ imipenem resistance in A.baumannii.

Erciyes University, Kayseri, Turkey

\section{Conclusion}

Surveillance of surgical site infections is one of the most important infection control issue. Prolonged use of AMP and use of broad spectrum antibiotics are associated with emergence of resistant bacterial strains.

\section{Disclosure of interest}

None declared.

Published: 29 June 2011

doi:10.1186/1753-6561-5-S6-P194

Cite this article as: Alp et al:. Incidence, risk factors and etiological

agents in surgical site infections in a developing country. $B M C$

Proceedings 2011 5(Suppl 6):P194. and take full advantage of:

- Convenient online submission

- Thorough peer review

- No space constraints or color figure charges

- Immediate publication on acceptance

- Inclusion in PubMed, CAS, Scopus and Google Scholar

- Research which is freely available for redistribution

Submit your manuscript at www.biomedcentral.com/submit 